Open Access

\title{
Hypericin-mediated photodynamic therapy induces apoptosis of myoloma SP2/0 cells depended on caspase activity in vitro
}

\author{
Junping Zhang ${ }^{1}$, Linxiang Shao ${ }^{2}$, Chunlin $\mathrm{Wu}^{3}$, Hongfei Lu² and Ruian $\mathrm{Xu}^{1 *}$
}

\begin{abstract}
Background: Photodynamic therapy (PDT) is becoming a promising therapeutic modality for hematological malignancies. Hypericin is a natural photosensitizer possessing anti-depressant, anti-virus and anti-cancer activities. The present study was designed to explore the effect and mechanism of hypericin-mediated PDT on the mouse multiple myeloma (MM) cells in vitro.

Methods: The mouse myeloma SP2/0 cells were incubed with different concentrations of hypericin and then illuminated with different light doses. The inhibitory effect of hypericin-mediated PDT on tumor cell proliferation was assayed by 3-(4, 5-dimethylthiazol-2-yl)-2, 5-diphenyltetrazolium bromide (MTT) method. The apoptosis related morphological changes of SP2/0 cells were observed by microscopy. The biochemical hallmarks of apoptosis such as DNA fragments, mitochondrial membrane potential changes were assessed. The expression of apoptosis related proteins were investigated by western blotting.
\end{abstract}

Results: Hypericin-mediated PDT induced the proliferation inhibition and apoptosis of tumor cells in a dose dependent manner. Tumor cells showed obvious morphological changes of apoptosis and necrosis and DNA fragmentation after treated by hypericin mediated PDT $(0.025 \sim 0.05 \mu \mathrm{M})$. The mitochondria membrane potential in SP2/0 cells was decreased significantly after incubated with the $0.025 \mu \mathrm{M}$ and $0.5 \mu \mathrm{M}$ hypericin $(P<0.05)$. The expression level of caspase-3 was decreased, while caspase activity was elevated with the increasing drug dosage. The apoptosis of SP2/0 cells was blocked by a pan-caspase inhibitor Z-VAD-FMK and caspase-3 inhibitor Ac-DEVD-CHO.

Conclusion: Hypericin-mediated PDT induced apoptosis mainly dependent on caspase related pathways. Hypericin-mediated PDT may be a potential and alternative therapy for MM.

Keywords: Multiple myeloma, Hypericin-mediated photodynamic therapy, SP2/0 cells, Apoptosis, Caspase

\section{Introduction}

Multiple myeloma (MM) as one of the lymphoid neoplasms, is characterized by the accumulation of abnormal plasma cells in bone marrow [1,2]. MM is the second most common hematological malignancy, accounting for $10 \%$ of all hematological malignancies. MM can affect various organs function in patients and result in a series of symptoms such as bone pain, renal failure, infection and neurological disorders [3-6]. It is estimated that total 14541 cases will suffer MM in the year of 2010

\footnotetext{
*Correspondence: ruianxuraxer@163.com

'Engineering Research Center of Molecular Medicine, Ministry of Education, China and School of Medicine, Huaqiao University, 269 Chenghua North Road, Quanzhou, Fujian Province 361021, China

Full list of author information is available at the end of the article
}

and the number of incidence cases are likely to increase to 21754 by 2020 in India [7]. In addition, the overall survival time for patients with MM ranges from 6 months to 10 years with mean of 3 to 4 years [8]. MM remains an incurable hematological malignancy, despite of conventional and advanced chemotherapy.

Presently, novel therapies are urgently needed. Photodynamic therapy (PDT) is a potential novel anticancer therapy that applied a photosensitizer and light to produce reactive oxygen in cells [9]. PDT can inactivate tumor cells in autologous bone marrow grafts and shows benefits in bone marrow transplantation substantially [10]. PDT has been applied in eradicating the malignant 
cells of the autograft in the autologous bone marrow transplantation for MM treatment [11]. Additionally, it is reported that PDT exerts stronger cytotoxicity in chronic myeloid leukemia (CML) cells than normal granulocyte/ macrophage progenitors and PDT can eliminate CML cells from malignant-normal bone marrow mononuclear cells mixture [12]. PDT is becoming a promising therapeutic modality for hematological malignancies, such as leukemia [13], lymphoma [14] and MM [11].

Hypericin, a natural polycyclic quinone, is mainly extracted from the plants of hypericum genus [15]. Hypericin has been regarded as a promising photosensitizing agent for its characteristic of light-dependent antineoplastic and antiviral activity [16]. Hypericin-mediated PDT has obtained increasing interests as a potential treatment for various cancers [17-19]. Currently, multiple pathways have been found to involved in the tumor cell death program induced by hypericin-mediated PDT, such as mitochondrial pathway [20,21], lysosomal damage [22], alternation of intracellular $\mathrm{pH}$ level [23,24], Bcl-2 phosphorylation by CDK-1 [25] as well as the increase of intracellular Ca2+ stimulated apoptosis [26-28]. However, the mechanism underlying hypericin-mediated PDT for MM suppression has been not clarified clearly.

In this study, we explore the mechanism of MM treatment and the type of cell death induced by PDT with hypericin by SP2/0 cells. The cellular morphology and the cell proliferation of SP $2 / 0$ cells were investigated at different concentrations of hypericin. The changes in the mitochondrial membrane potential and the activation of Caspase related pathways were further assessed. The aim of the present study was to investigate the effect and mechanism of hypericin-mediated PDT on the mouse MM cells in vitro.

\section{Materials and methods}

Hypericin preparation and cell culture

Hypericin powder (Beijing Standard Herbs Medical Science \& Technology Development Co. LTD., Beijing, China) with purity $>98 \%$ was determined by highperformance liquid chromatography (HPLC). A stock solution of hypericin $(10 \mathrm{mM})$ was prepared with dimethyl sulfoxide (DMSO; Sigma) and stored at $-20^{\circ} \mathrm{C}$ in the dark. Immediately before each experiment, the working solution of hypericin was diluted in RPMI1640 medium without serum to obtain a final concentration.

The mouse myeloma cell line SP2/0 (ATCC) was from American Type Culture Collection. The cells were cultured in RPMI1640 medium supplemented with $10 \%$ calf serum, $2.2 \mathrm{~g} / \mathrm{l} \mathrm{NaHCO}$, $100 \mathrm{U} / \mathrm{ml}$ penicillin, and $100 \mathrm{~g} / \mathrm{ml}$ streptomycin. Cells were maintained in a humidified atmosphere with $5 \% \mathrm{CO}_{2}$ at $37^{\circ} \mathrm{C}$ until the logarithmic growth phase based on the cell growth curve. The adherent cells were displaced by rinsing with $0.25 \%$ trypsin.
Then, the adherent and suspension cells were harvested for the following experiments.

\section{PDT treatment}

SP2/0 cells $\left(5 \times 10^{4}\right.$ cells $\left./ \mathrm{ml}\right)$ were seeded on 96-well plates $(100 \mu \mathrm{l} /$ well $)$ and incubated with hypericin at different concentration $(0.001,0.01,0.1,1$ and $10 \mu \mathrm{M})$ for 16 hours in the dark. Cells were given external $7 \mathrm{~cm}$ illumination treatment on a plastic diffuser sheet above a set of 6 yellow L18W/30 lamps (CH Lighting, Zhejiang, China) with the maximum spectrum range of 570-620 $\mathrm{nm}$. Irradiation intensity was detected to be under 13000 lux by TES-1332A (TES, Taiwan, China). The total light doses were determined to be $2.82,5.64,8.46,11.28$ and $14.10 \mathrm{~J} / \mathrm{cm}^{2}$ by a photometer. During the illumination, the temperature of the samples ranged from 32 to $37^{\circ} \mathrm{C}$. After PDT treatment, cells were maintained for 24 hours at $37^{\circ} \mathrm{C}$ in a humidified atmosphere of $95 \%, 5 \% \mathrm{CO}_{2}$ until further analysis.

\section{The 3-(4, 5-dimethylthiazol-2-yl)-2, 5-diphenyltetrazolium} bromide (MTT) assay

In order to determine the optimal hypericin concentration or irradiation dose for PDT treatment, we performed MTT assay to analyze the proliferation of SP2/0 cells [29]. Briefly, SP2/0 cells at a final density of $5 \times 10^{4}$ cells $/ \mathrm{ml}$ (100 $\mu \mathrm{l} /$ well), were incubated with hypericin at a concentration gradient from 0.001 to $10 \mu \mathrm{M}$ for 16 hours in the dark. The cell plates were illuminated with different light dose of $0,2.82,5.64,8.46,11.28$ and $14.10 \mathrm{~J} / \mathrm{cm}^{2}$, and then incubated for 24 hours in the dark. To obtain the $\mathrm{IC}_{50}$, $\mathrm{SP} 2 / 0$ cells were treated with indicated concentrations of hypericin $(0,0.0125,0.025,0.05$ and $0.1 \mu \mathrm{M})$ for 16 hours in the dark. Subsequently, the cells were illuminated at a light dose of $11.28 \mathrm{~J} / \mathrm{cm}^{2}$ for 24 hours in the dark.

SP2/0 cells without any treatment were set as controls. The MTT assay was performed for SP2/0 cells at each condition according to the manufacturer's instructions. In brief, $10 \mu \mathrm{l}$ of MTT ( $5 \mathrm{mg} / \mathrm{ml}$; Sigma) was added in each well for 4 hours at $37^{\circ} \mathrm{C}$. After removal of the medium, the MTT crystals were dissolved with $100 \mu \mathrm{l}$ DMSO for $15 \mathrm{~min}$. The absorbance at $550 \mathrm{~nm}$ was measured by a Multiskan Spectrum 1500 (Thermo Electron Corporation, USA). The inhibition rate of cell proliferation was calculated as follows: (A550control - A550treated)/ A550control $\times 100 \%$ and the $\mathrm{IC}_{50}$ value was obtained by Logit method [30].

\section{Light and fluorescence microscopy}

SP2/0 cells $\left(1 \times 10^{5}\right.$ cells $\left./ \mathrm{ml}\right)$ were seeded into the 6 -well plates $(2 \mathrm{~mL} /$ well $)$ and incubated with hypericin at the final concentrations of $0.025,0.05$ or $0.1 \mu \mathrm{M}$ for 16 hours in the dark. Subsequently, the plates were illuminated at a light dose of $11.28 \mathrm{~J} / \mathrm{cm}^{2}$ for $24 \mathrm{~h}$. The 
adherent and suspension cells were collected for the following morphological analysis according to the method described above.

A part of cells were harvested and observed by a phasecontrast microscopy. Some cells were collected for Hoechst 33342/propidium iodide (PI) co-staining [31]. SP2/0 cells were stained with Hoechst $33342(5 \mu \mathrm{g} / \mathrm{ml})$ and PI $(5 \mu \mathrm{g} / \mathrm{ml})$ at room temperature for $10 \mathrm{~min}$, then examined under a fluorescence microscopy (E600, Nikon, Japan) with excitation at $360 \mathrm{~nm}$ [32]. Intact blue nuclei of viable cells, condensed/fragmented bright blue nuclei of apoptotic (early or late) cells and pink nuclei of necrotic cells can be observed. The number of apoptotic or necrotic cells was counted in a total of 200 cells from 5 random fields.

\section{Transmission electron microscopy (TEM)}

SP2/ 0 cells $\left(1 \times 10^{5}\right.$ cells $/ \mathrm{ml}, 2 \mathrm{~mL} /$ well $)$ treated with hypericin $(0.025,0.05$ or $0.1 \mu \mathrm{M})$ and illumination $\left(11.28 \mathrm{~J} / \mathrm{cm}^{2}\right)$ were collected for TEM examination. Samples were prepared as described previously [33]. The cells were fixed with $2.5 \%$ glutaraldehyde, followed by $1 \% \mathrm{OsO}_{4}$ and then dehydrated with acetone. They were embedded in Epon812-resin mixture. Serial sections (about $50 \mathrm{~nm}$ ) were obtained by ultra-microtome. Sections were stained with sodium acetate and lead citrate and then viewed by a Hitachi H-7000/STEM electron microscope (Hitachi Inc., Tokyo, Japan) at $75 \mathrm{kV}$.

\section{DNA fragments}

SP2/0 cells with hypericin $(0.025,0.05$ and $0.1 \mu \mathrm{M})$ and illumination $\left(11.28 \mathrm{~J} / \mathrm{cm}^{2}\right)$ were used for this experiment. The suspension cells and adhesive cells on the 6-well plates were all collected for DNA extraction following the manufacturer's instructions of DNA Ladder Extraction Kit with Spin Column (Beyotime Institute of Biotechnology, China). The DNA extractions $(40 \mu \mathrm{g})$ were separated on $1.0 \%$ agarose gel containing ethidium bromide (EB) and were visualized under UV light. Standard molecular weight markers (Fermentas, MBI) were run on the lefthand lane of the gel.

The 5, 5', 6, 6'-tetrachloro-1, 1', 3, 3 '-tetraethylbenzimidazolyl-carbocyanine iodide (JC-1) staining

In order to explore the changes in the membrane potential, we carried out JC- 1 staining for SP2/0 cells intervened by hypericin $(0,0.025$ and $0.05 \mu \mathrm{M})$ and illumination $\left(11.28 \mathrm{~J} / \mathrm{cm}^{2}\right)$. The collapse of the mitochondrial membrane was measured using a mitochondrial membrane potential assay kit with JC-1 (Beyotime Institute of Biotechnology, China) [34]. JC-1 formed aggregates in the mitochondria at relatively high membrane potential exhibiting red-orange fluorescent at $590 \mathrm{~nm}$. The JC-1 monomers distributed in the cytoplasm of cells with low potential and emitted a green fluorescent at $529 \mathrm{~nm}$. After JC-1 staining, cells were analyzed by flow cytometry with green emission in channel 1 (FL1) and red emission in channel 2 (FL2). The relative ratio of JC-1 aggregate (FL2, red fluorescence intensity) to monomer (FL1, green fluorescence intensity) was calculated. A decrease in this ratio was defined as the depolarization of the mitochondrial membrane potential.

\section{Propidium iodide $(\mathrm{PI})$ staining}

To evaluate the effects of caspase inhibitors (pan-caspase inhibitor Z-VAD-FMK or caspase-3 inhibitor Ac-DEVD$\mathrm{CHO}$ ) on apoptosis mediated by hypericin with PDT, the PI staining was carried out. The caspase inhibitors were dissolved in DMSO at a storage $20 \mathrm{mM}$ concentration. $\mathrm{SP} 2 / 0$ cells were pre-incubated with the pan-caspase inhibitor $(100 \mu \mathrm{M})$ or caspase-3 inhibitor $(100 \mu \mathrm{M})$ for $1 \mathrm{~h}$, and then exposed to $0.05 \mu \mathrm{M}$ hypericin for $16 \mathrm{~h}$ in the dark. Preliminary experiment indicated that $0.125 \%$ DMSO had little effect on the cell death and proliferation. For PI staining, the caspase inhibitors were dissolved in $0.05 \%$ DMSO that was safe for SP2/0 cells. After illuminated at $11.28 \mathrm{~J} / \mathrm{cm}^{2}$ for $24 \mathrm{~h}, \mathrm{SP} 2 / 0$ cells were harvested, fixed in $70 \%$ ethanol and stored at $4^{\circ} \mathrm{C}$ overnight. Then, cells were stained with PBS containing $40 \mu \mathrm{g} / \mathrm{mL}$ RNase and $10 \mu \mathrm{g} / \mathrm{mL}$ PI at room temperature for $30 \mathrm{~min}$ in the dark. Cells were analyzed using an FACS-Calibur flow cytometer (Becton Dickinson, San Jose, CA, USA). The cells during apoptosis were obtained from the distinct sub-G1 region of the DNA distribution histograms. At least 20,000 events were counted for each sample.

\section{Caspase- 3 activity assay}

SP2/0 cells at a final density of $1 \times 10^{5}$ cells $/ \mathrm{ml}$ were grown in 6-well plates $(2 \mathrm{~mL} /$ well $)$ and incubated with the hypericin $(0.025$ and $0.05 \mu \mathrm{M})$ for 16 hours. The untreated cells were defined as control. After $24 \mathrm{~h}$ illumination at $11.28 \mathrm{~J} / \mathrm{cm}^{2}$, caspase- 3 activity was determined using a caspase- 3 activity kit (Beyotime, Nanjing, China) which was based on the ability of caspase- 3 to change acetyl-Asp-Glu-Val-Asp p-nitroanilide into the yellow formazan product, p-nitroaniline. The absorbance at 405 $\mathrm{nm}$ was measured for cells treated with hypericin with PDT and controls. The formula was listed as follows:

Activity of caspase $3=\frac{O D_{405 \mathrm{~nm}} \text { of treated cells }}{O D_{405 \mathrm{~nm}} \text { of controls }}$

\section{Western blotting}

Western blot analysis was performed as previously described [35-37]. Protein samples $(40 \mu \mathrm{g})$ were separated by $8-12 \%$ ( $8 \%$ for PARP-1; $10 \%$ for AIF, $\beta$-actin; $12 \%$ for 
Bcl-2, Bax, Cytochrome c, Histone 2A, Caspase-3) sodium dodecyl sulfate-polyacrylamide gels electrophoresis and transferred to polyvinylidene fluoride membrane (Immobilon PVDF, Millipore). The membranes were blocked in 10\% non-fat dried milk in TBS-T (10 mM Tris- $\mathrm{HCl}$ (pH 8.0), $150 \mathrm{mM} \mathrm{NaCl}$, and 0.1\% Tween) for 2 hours at room temperature. Then the membranes were incubated with the primary antibodies of anti-Bcl-2 rabbit monoclonal antibody (1:1000), anti-Bax rabbit monoclonal antibody (1:1000), anti-caspase-3 rabbit polyclonal antibody (1:1000), anti-PARP rabbit polyclonal antibody (1:1000), anti- $\beta$-actin mouse polyclonal antibody (1:1000), anti-cytochrome $c$ rabbit monoclonal antibody (1:1000), anti-AIF rabbit monoclonal antibody (1:1000), and antiH2AX rabbit monoclonal antibody (1:500), respectively, overnight at $4^{\circ} \mathrm{C}$. All the antibodies were purchased from Cell Signaling Technology (Beverly, MA, USA). Subsequently, membranes were washed three times with Trisbufffered saline, $0.1 \%$ Tween-20 and then incubated with the peroxidase-conjugated secondary antibodies for $1 \mathrm{~h}$. The membranes were washed three times again and developed using enhanced chemiluminescence (ECL, Amersham Biosciences). Bands were visualized using the $\mathrm{ChemiDoc}^{\text {тM }}$ XRS+ System with Image Lab ${ }^{\mathrm{Tm}}$ Software (Bio-rad, USA). Protein expressions were quantified by densitometry analyzed using Quantity One 4.5.2 software (Bio-Rad, Hercules, USA).

\section{Statistical analysis}

All the data were displayed as mean \pm standard deviation (SD). All the statistical analysis was performed by SPSS17.0 statistical software. Differences among groups were analyzed with S-N-K followed by One-Way ANOVA. $P$ value $<0.01$ was considered to be statistically significant.

\section{Results}

\section{Hypericin mediated PDT inhibited the proliferation of} SP2/0 cells

The inhibitory effect of hypericin on the proliferation of SP2/0 cells was determined following photoactivation. As shown in Figure 1A, treatment of hypericin or PDT alone showed little effect on preventing the proliferation of SP2/0 cells. After the cells were incubated with different concentrations of hypericin $(0.001,0.01,0.1,1$ and $10 \mu \mathrm{M})$ for 16 hours and then exposed to various fluencies of irradiation $\left(0-14.10 \mathrm{~J} / \mathrm{cm}^{2}\right)$, the proliferation of SP2/0 cells was inhibited significantly with the increasing drug concentration and light dose. When cells were irradiated with $8.46 \mathrm{~J} / \mathrm{cm}^{2}$ light dose, the inhibition rates of cell proliferation were $2.20 \pm 0.76 \%, 26.19 \pm 0.95 \%$, $75.75 \pm 0.93 \%, 90.07 \pm 1.35 \%$ and $95.88 \pm 1.26 \%$ with the hypericin concentrations ranging from 0.001 to $10 \mu \mathrm{M}$, respectively. Similarly, for the cells with $0.1 \mu \mathrm{M}$ hypericin treatment, the inhibitory rates were $2.51 \pm 0.79 \%$,
$50.1 \pm 0.88 \%, \quad 75.75 \pm 0.93 \%, 95.53 \pm 0.89 \%$ and $96.25 \pm$ $1.05 \%$ at 2.82 to $14.10 \mathrm{~J} / \mathrm{cm}^{2}$ light doses, respectively. In addition, with the high hypericin concentration of $1 \mu \mathrm{M}$, cells showed similar proliferation inhibitory rate of $82.68 \%$ and $87.89 \%$ at light dose of 11.28 and $14.12 \mathrm{~J} / \mathrm{cm}^{2}$, respectively $(\mathrm{P}>0.05)$. Therefore, the light dose of $11.28 \mathrm{~J} / \mathrm{cm}^{2}$ was selected for further experiments.

There was a positive linear correlation between the inhibition rate and hypericin concentration $\left(R^{2}=0.955\right)$ and the value of $\mathrm{IC}_{50}$ was $0.035 \pm 0.003 \mu \mathrm{M}$ at condition of hypericin $(0,0.0125,0.05$ or $0.1 \mu \mathrm{M})$ with light dose of $11.28 \mathrm{~J} / \mathrm{cm}^{2}$ (Figure 1B). These results suggested that hypericin-mediated PDT inhibited the proliferation of SP2/0 cells effectively in a concentration and light-dose dependent manner.

\section{Hypericin-mediated PDT induced obvious morphological changes of apoptosis in SP2/0 cells}

After hypericin mediated PDT treatment for 24 hours, phase-contrast microscopy observation showed that SP2/0 cells had obvious morphological changes such as cell shrinkage and membrane bleb formation in a drug concentration-dependent manner, in comparison of untreated cells (Figure 2A). As shown in Figure 2B and D, most of the nuclei were round and blue in controls with the percentage of $94.97 \pm 0.26 \%$. Bright apoptotic nuclei characterized by chromatin condensation or fragments were found in the groups treated by PDT with hypericin at 0.025 and $0.05 \mu \mathrm{M}$ and the percentage of apoptotic cells was $39.18 \pm 1.34 \%$ and $63.52 \pm 2.81 \%$, respectively. While in the $0.1 \mu \mathrm{M}$ hypericin with PDT treatment group, most nuclei $(71.84 \pm 3.09 \%)$ were diffused and stained with pink, and there were a few bright condensed nuclei.

Furthermore, TEM analysis revealed that hypericinmediated PDT induced obvious morphological changes of SP2/0 cells. The control cells showed abundant cytoplasm and apparent nuclei with uniformly dispersed chromatin. After exposed to $0.025 \mu \mathrm{M}$ hypericin with PDT, cells exhibited the typical characteristics of early stage apoptosis such as nuclear membrane contraction and chromatin marginalization. When exposed to $0.05 \mu \mathrm{M}$ hypericin with PDT, cells were characterized by nuclear fragmentation, intense vacuolization and a large number of apoptotic body formations. At the condition of $0.1 \mu \mathrm{M}$ hypericin with PDT, there appeared the necrotic cell death, which displayed ruptured plasma membrane, swollen mitochondrial, irregular chromatin destruction (Figure 2C).

\section{Hypericin-mediated PDT induced DNA fragmentation in SP2/0 cells}

In order to assess the hallmark of apoptosis in seSP $2 / 0$ cells responding to the treatment of hypericin-mediated PDT, DNA from SP2/0 cells at different hypericin concentrations of $0.025,0.05$ and $0.1 \mu \mathrm{M}$ were extracted 

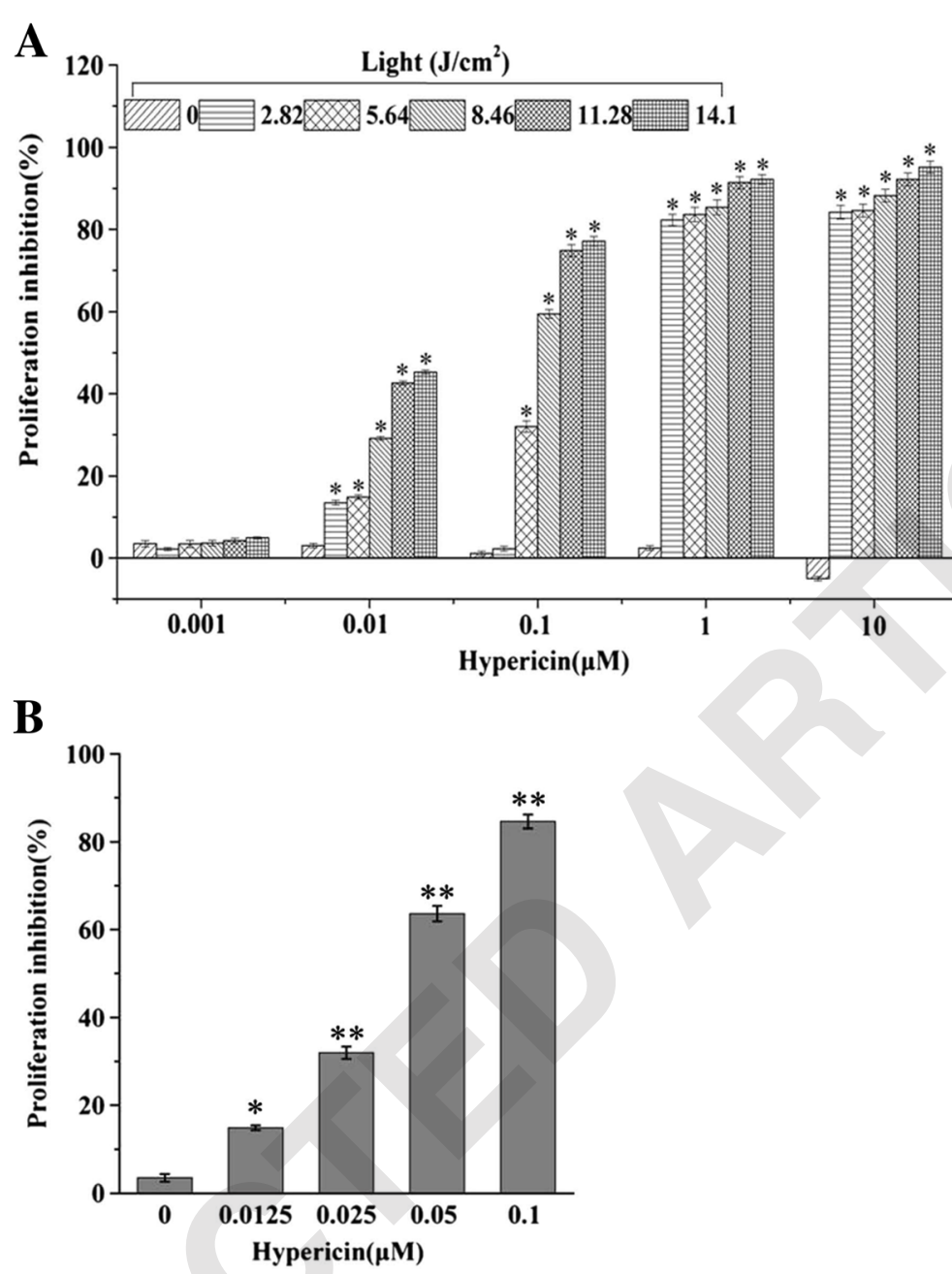

Figure 1 Proliferation of SP2/0 cells determined by MTT assay. (A) SP2/0 cells were treated with different concentrations of hypericin (0-10 $\mu M$ ) and irradiation doses $\left(0-14.12 \mathrm{~J} / \mathrm{cm}^{2}\right)$ for 24 hours. (B) SP2/0 cells were treated with different concentrations of hypericin $(0-0.1 \mu \mathrm{M})$ and irradiation dose of $11.28 \mathrm{~J} / \mathrm{cm}^{2}$ ) for 24 hours. Results were shown as mean $\pm \mathrm{SD}, \mathrm{n}=5,{ }^{*} p<0.01$.

and observed following agarose gel electrophoresis. As shown in Figure 3, PDT mediated cells treated by hypericin at concentration of $0.025,0.05 \mu \mathrm{M}$ exhibited a characteristic DNA laddering by agarose gel electrophoresis. However, there were limited fragments for DNA from $0.1 \mu \mathrm{M}$ hypericin treated cells and no DNA fragments were observed in untreated cells and cells treated with PDT alone.

\section{Hypericin-mediated PDT induced loss of mitochondria membrane potential in SP2/0 cells}

The changes in the mitochondrial membrane potential of SP2/0 cells were detected by JC-staining with flow cytometry. After hypericin-mediated PDT treatment, the red-orange mitochondrial fluorescence decreased, while more of the green fluorescence (JC-1 monomer) was observed in cytoplasm (Figure 4A,B). Compared with cells with only post-radiation therapy (3.61), the ratio of JC-red/JC-green was significantly decreased in cells intervened by PDT with hypericin at $0.025 \mu \mathrm{M}(1.74)$ and $0.05 \mu \mathrm{M}$ (0.47), $(\mathrm{P}<0.05)$ which suggested that the loss of mitochondrial membrane potential (Figure $4 \mathrm{C}$ ).

Hypericin-mediated PDT activated both caspase-dependent and AIF mediated caspase-dependent signaling pathways The protein levels in SP2/0 cells treated by hypericinmediated PDT $(0.025$ and $0.05 \mu \mathrm{M})$ for $24 \mathrm{~h}$ were analyzed. Western blot analysis showed that the expression of Bcl-2 was down-regulated by $35 \%$, while the expression of Bax was up-regulated by $13.4 \%$. Thus, the Bax/ Bcl-2 ratio increased from 1 to 3.6 folds, compared with cells in control (0 $\mu \mathrm{M}$ hyericin treatment). Additionally, hypericin-mediated PDT induced the increased expression of cytochrome $c$ and AIF (Figure 5). Furthermore, 


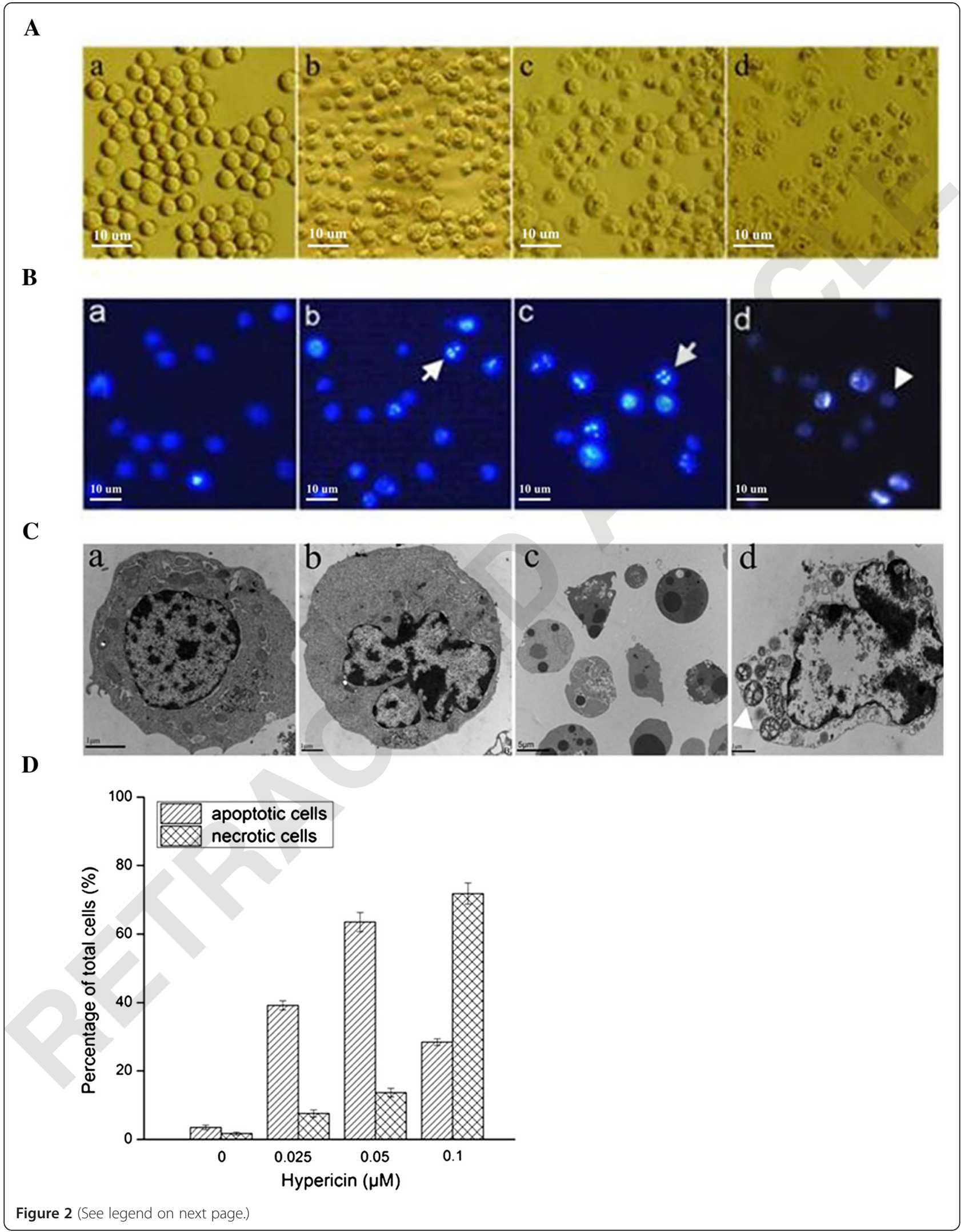


(See figure on previous page.)

Figure 2 Morphological changes assayed in SP2/0 cells exposed to the indicated concentrations of hypericin at $24 \mathrm{~h}$ after applying $11.28 \mathrm{~J} / \mathrm{cm}^{2}$ irradiation dose. (A) Light microscopy analysis of morphological alternations in SP2/0 cells. (a) Untreated control cells. (b), (c) and (d) Cells treated with hypericin at $0.025,0.05$ or $0.1 \mu \mathrm{M}$. Bar $=10 \mu \mathrm{m}$ (B) Apoptotic or necrotic nuclei of SP2/0 cells evaluated using fluorescence microscopy with Hoechst 33342 (blue)/PI (red) double staining. (a) Untreated control cells. (b), (c) and (d) Cells treated with hypericin at 0.025, 0.05 or $0.1 \mu \mathrm{M}$. Arrow: apoptotic nuclei; Arrow head: necrotic nuclei. Bar $=10 \mu \mathrm{m}$. (C) TEM analysis of ultrastructural alternations of SP2/0 cells. (a) Untreated control cells. (b), (c) and (d) Cells treated with hypericin at 0.025, 0.05 or $0.1 \mu \mathrm{M}$. Arrow: apoptotic bodies; Arrow head: swollen mitochondria. (D) The percentage of apoptotic or necrotic nuclei was analyzed in a total of 200 cells from five random areas.

the expression level of caspase-3 was decreased, while caspase activity was elevated with the increasing drug dosage (Figures 5 and 6). The caspase-3-mediated cleavage of the $116-\mathrm{kDa}$ PARP protein into $89-\mathrm{kDa}$ was also enhanced in a dose-dependent manner and $0.05 \mu \mathrm{M}$ hypericin-mediated PDT caused almost complete cleavage (Figure 5).

\section{Hypericin-mediated PDT induced apoptosis dependent on caspase}

To investigate whether apoptosis induced by hypericinmediated PDT dependent on the activation of capases, SP2/0 cells were pretreated with the $100 \mu \mathrm{M}$ pan-caspase inhibitor (Z-VAD-FMK) or $100 \mu \mathrm{M}$ caspase-3 inhibitor (Ac-DEVD-CHO) for $1 \mathrm{~h}$. Flow cytometry analysis showed

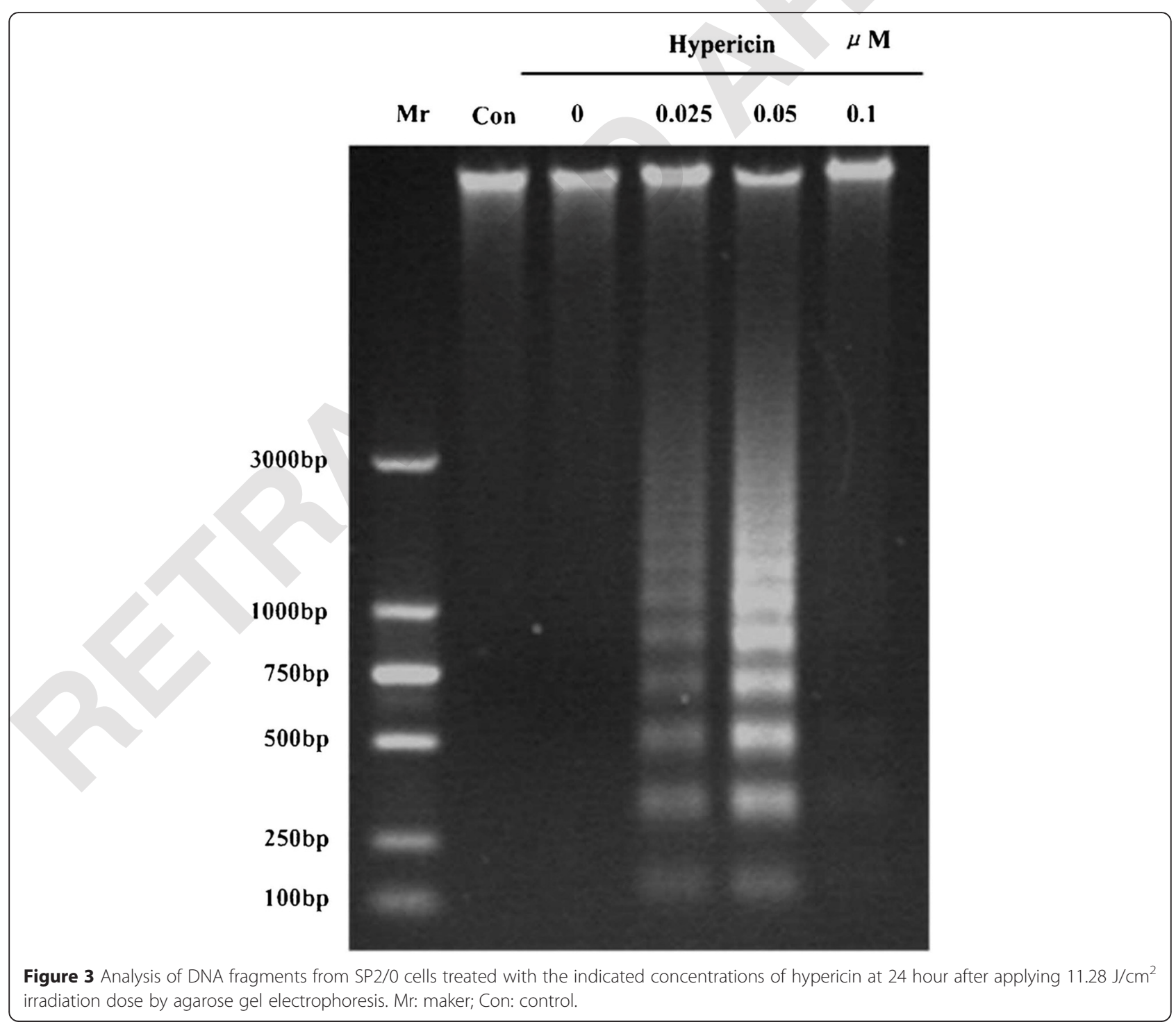




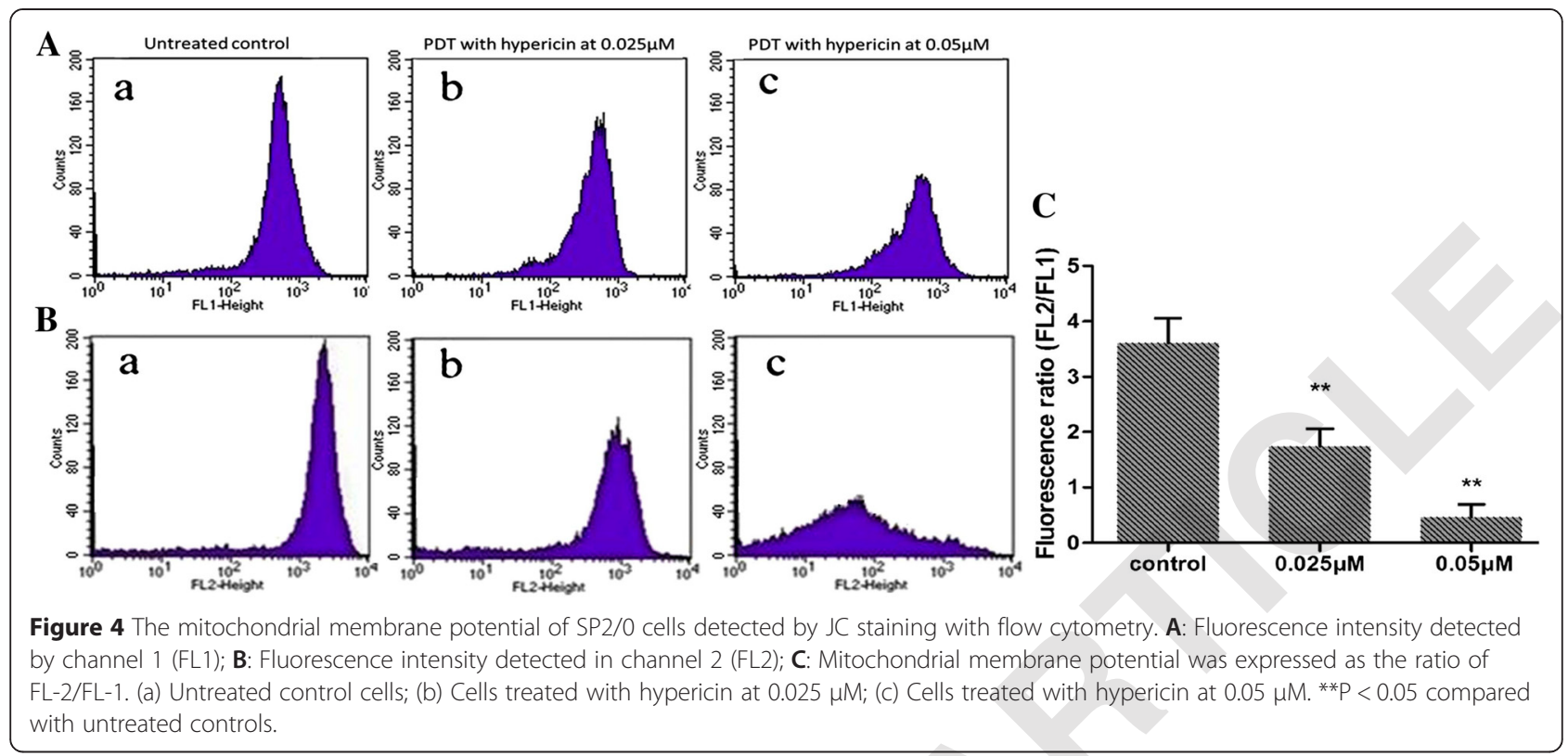

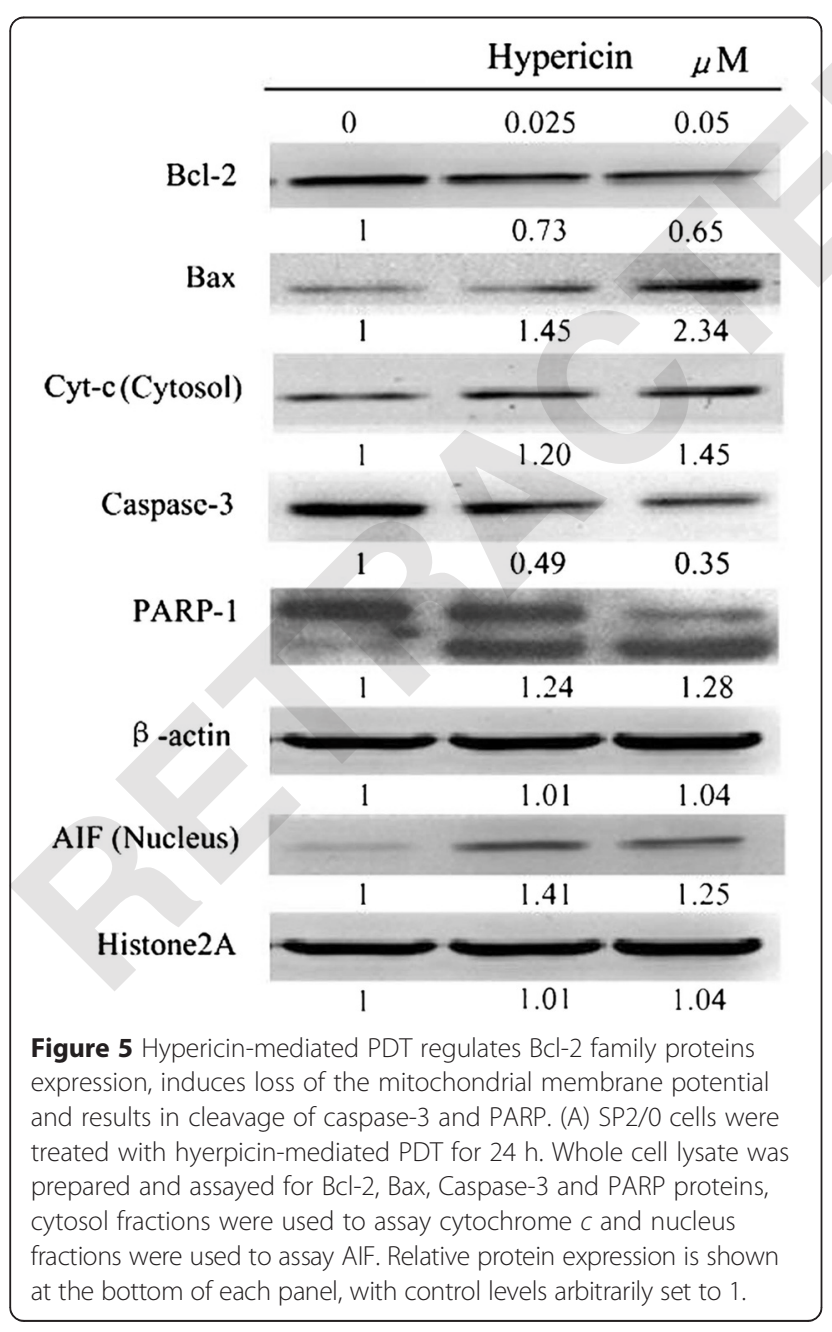

that the apoptosis cell rate of SP2/0 cells was $3.51 \%$ in the controls, while the apoptosis rate was up to $56.47 \%$ in the hypericin-mediated PDT group $(0.05 \mu \mathrm{M})$ (Figure 7). Moreover, the apoptosis rate of cells pretreated with zVADfmk (5.32\%) or Ac-DEVD-CHO (7.43\%) decreased obviously after hypericin- mediated PDT treatment (Figure 7).

\section{Discussion}

$\mathrm{MM}$ is the most common bone marrow malignancy. It is reported that there are 114,000 cases diagnosed with MM and 80,000 deaths resulting from MM in 2010 worldwide [38]. MM remains an incurable bone malignancy with severe complications and poor prognosis for MM patients. The increasing studies for MM treatment contribute to the evolution of therapies, the increase of survival time and the improvement of life quality for patients [39]. Hypericin-mediated PDT is reported to be an attractive candidate treatment modality for human cancer cells [40]. The evidence of the inhibitive effect of hypericinmediated PDT on MM is insufficient. In this study, we further explored the mechanism of the apoptosis of mouse myeloma SP2/0 cells induced by hypericin-mediated PDT at different concentrations of hypericin.

Our results showed that the combination of hypericin with PDT showed great inhibitive effects on the proliferation of SP2/0 cells and led to extensive apoptosis. After tumor cells were incubated with different concentrations of hypericin (0.01-10 $\mu \mathrm{M})$ and then exposed to illumination with different light doses $(0-14.10 \mathrm{~J} / \mathrm{cm} 2)$, data from MTT assay revealed that hypericin or illumination treatment alone had no obvious effect on inhibiting the proliferation of SP2/0 cells. Hypericin combined with illumination caused significant drug concentration- 


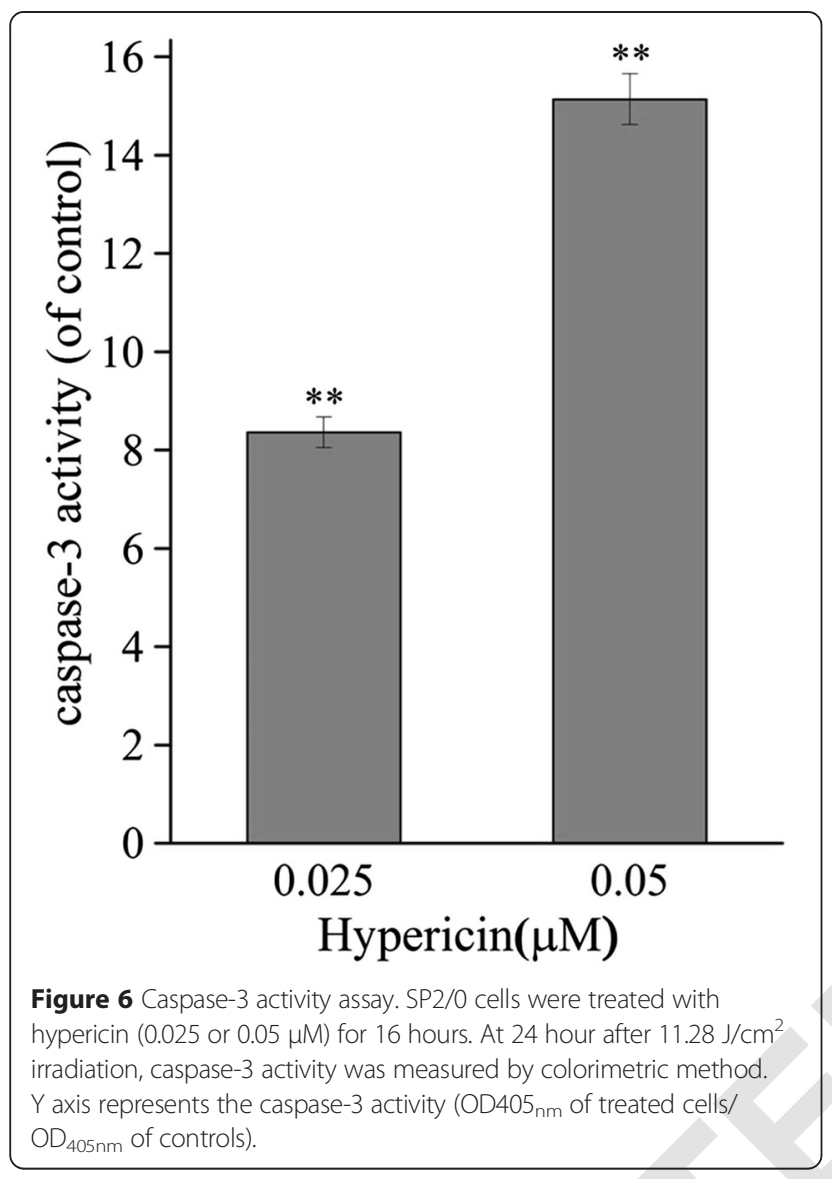

and light intensity-dependent manner in the inhibition of SP2/0 cells proliferation. The metabolic activity of $\mathrm{SP} 2 / 0$ cells was reduced significantly with the increasing hypericin concentration and light dose. Additionally, we found that under the same concentration of hypericin, high light dose $\left(11.28\right.$ and $\left.14.10 \mathrm{~J} / \mathrm{cm}^{2}\right)$ caused comparable effect on the cell proliferation inhibition, and the higher concentrations of hypericin $(1$ and $10 \mu \mathrm{M})$ caused equal inhibitory effect on the tumor cell proliferation, under the same illumination, which indicated that there might be a saturation of photochemical dose in PDT treatment on the MM. In order to avoid the damage caused by excess photosensitizing drug, the optimal treatment condition leading to the appropriate energy state results for MM patients should be further studied.

Apoptosis has been determined to be the most prominent event in the tumor tissue destruction induced by hypericin-mediated PDT $[41,42]$. In order to assess the involvement of apoptosis in tumor response to hypericinmediated PDT, the hallmarks of apoptosis including DNA fragmentation and morphological changes were investigated in this paper. Results showed that low doses of PDT with hypericin $(0.025$ and $0.05 \mu \mathrm{M})$ induced apparent morphological and biochemical characteristics of apoptosis in SP2/0 cells such as cell shrinkage, chromatin condensation, formation of apoptotic bodies as well as DNA laddering, while high dose of PDT with hypericin $(0.1 \mu \mathrm{M})$ led to cell necrosis (Figures 2 and 3$)$. As outlined in previous studies, apoptosis induced by PDT can be observed at lower hypericin concentrations and fewer light intensities, whereas necrosis occurs at high hypericin concentrations and light intensities [43,44], which is consistent with our findings. The transitions from apoptosis to necrosis in a drug and light dose-dependent manner induced by hypericin with PDT have also been observed in HeLa cells and human epidermoid carcinoma cells in vitro [20,21]. All these showed that hypericin-mediated PDT is a potent inducer of apoptosis or necrosis in MM SP2/0 cells depended on the dosage of PDT, despite of the factors such as the location of the photosensitizer, the nature of photosensitizer as well as the genetic and metabolic potential of the cell type.

It is demonstrated that the apoptosis induced by hypericin-mediated PDT mainly resulted from the activation of apoptosis related pathways in response to the oxidative stresss and other signals [45]. It is reported that the apoptosis pathways induced by hypericin-mediated

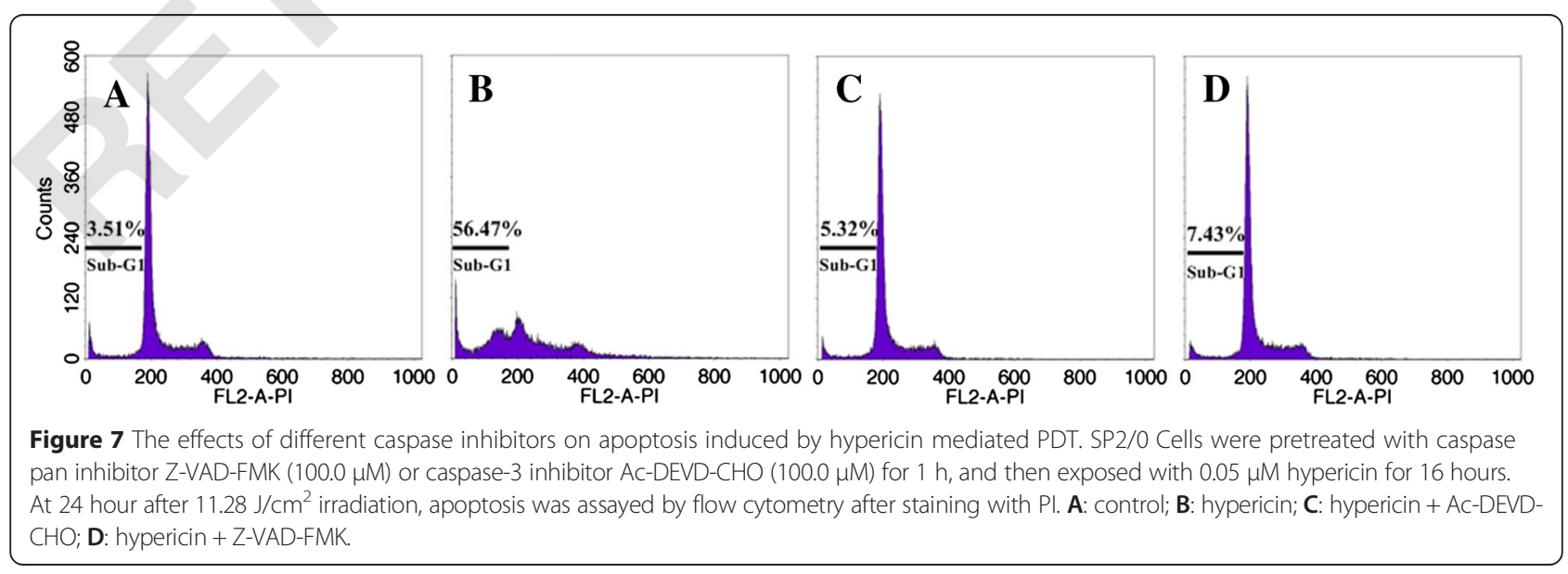


PDT are involved with plasma membrane death receptors, mitochondria, lysosomes and ER, caspases, and Bcl-2 family proteins [46]. Bcl-2 family proteins play key roles in the mitochondria-mediated cell death [47]. The expression of Bcl-2 family proteins can induce the mitochondrial membrane permeabilization, which causes the release of caspases or apoptosis inducing factor (AIF) [48]. The upregulation of $\mathrm{Bax} / \mathrm{Bcl}-2$ ratio is found to be associated with the decrease of mitochondrial membrane potential that inhibits the growth of cancer cell growth [49].

In the present study, results of western blotting suggested that the expression of anti-apoptotic Bcl-2 protein was decreased and pro-apoptotic Bax protein was increased induced by hypericin-mediated PDT and thus shifted the $\mathrm{Bax} / \mathrm{Bcl}-2$ ratio that leaded to loss of the mitochondrial membrane potential in favor of cytochrome $c$ and AIF release. In the apoptosis process, the release of cytochrome $c$ induced the activation of caspase- 9 and then activates caspase-3 [50]. Caspase-3-mediated cleavage of the $116-\mathrm{kDa}$ PARP protein into $89-\mathrm{kDa}$ fragments is a hallmark of apoptosis [51]. The present study also showed that caspase-3 activity was increased that contributed to PARP cleavage and DNA degradation.

In fact, cytochrome $c$-mediated capsase dependent apoptotic pathway and AIF mediated caspase independent apoptotic pathway are complicated but not completely independent. AIF in the cytosol could promote cytochrome $c$ to be released from mitochondria and the activated caspases also facilitate translocation of AIF from mitochondria to the nucleus [52]. Besides, the present study further showed that the apoptosis induced by hypericin-mediated PDT was inhibited significantly by the pan-caspase inhibitor zVAD-fmk or special caspase-3 inhibitor Ac-DEVD$\mathrm{CHO}$. All these indicated that AIF release might be facilitated by casapse and hyerpicin with PDT induced apoptosis mainly depended on caspase-mediated cell death pathways.

\section{Conclusions}

Hypericin-mediated PDT could significantly inhibit the proliferation and induce apoptosis in myeloma SP2/0 cells. The apoptosis induced by hypericin-mediated PDT mainly depended on the caspase-mediated cell death pathway. Hypericin-mediated PDT may be a promising and alternative strategy for the treatment of MM.

\section{Competing interests}

The authors declare that they have no competing interest to disclose.

\section{Authors' contributions}

JZ and LS participated in the design of this study, and they both performed the statistical analysis. CW carried out the study, together with $\mathrm{HL}$, collected important background information, and drafted the manuscript. RX conceived of this study, and participated in the design and helped to draft the manuscript. All authors read and approved the final manuscript.

\section{Acknowledgements}

We wish to express our warm thanks to Fenghe (Shanghai) Information Technology Co., Ltd. Their ideas and help gave a valuable added dimension to our research.

\section{Author details}

${ }^{1}$ Engineering Research Center of Molecular Medicine, Ministry of Education, China and School of Medicine, Huaqiao University, 269 Chenghua North Road, Quanzhou, Fujian Province 361021, China. ²Department of Bioscience, College of Chemistry and Life Science, Zhejiang Normal University, Jinhua 321004, China. ${ }^{3}$ Department of Pathology, Second Affiliated Hospital of Fujian Medical University, Quanzhou 36200, China.

Received: 27 June 2014 Accepted: 21 November 2014 Published: 19 December 2014

\section{References}

1. BladÉ J, Samson D, Reece D, Apperley J, BJÖrkstrand B, Gahrton G, et al. Criteria for evaluating disease response and progression in patients with multiple myeloma treated by high-dose therapy and haemopoietic stem cell transplantation. Br J Haematol. 1998;102(5):1115-23.

2. Greene FL. AJCC cancer staging manual. vol. 1: Springer; 2002.

3. Raab MS, Podar K, Breitkreutz I, Richardson PG, Anderson KC. Multiple myeloma. Lancet. 2009:374(9686):324-39.

4. Alexanian R, Barlogie B, Dixon D. Renal failure in multiple myeloma. Arch Intern Med. 1990;150(8):1693-5.

5. Twomey JJ. Infections complicating multiple myeloma and chronic lymphocytic leukemia. Arch Intern Med. 1973;132(4):562-5.

6. Dispenzieri A, Kyle RA. Neurological aspects of multiple myeloma and related disorders. Best Pract Res Clin Haematol. 2005;18(4):673-88.

7. Takiar R, Nadayil D, Nandakumar A. Projections of number of cancer cases in India (2010-2020) by cancer groups. Asian Pac J Cancer Prev. 2010;11(4):1045-9.

8. Greipp PR, San Miguel J, Durie BG, Crowley JJ, Barlogie B, Bladé J, et al. International staging system for multiple myeloma. J Clin Oncol. 2005;23(15):3412-20.

9. Oleinick NL, Morris RL, Belichenko I. The role of apoptosis in response to photodynamic therapy: what, where, why, and how. Photochem Photobiol Sci. 2002;1(1):1-21.

10. Sieber F. Phototherapy, photochemotherapy, and bone marrow transplantation. J Hematother. 1993;2(1):43-62.

11. Brasseur N, Menard I, Forget A, Jastimi R, Hamel R, Molfino N, et al. Eradication of Multiple Myeloma and Breast Cancer Cells by TH9402mediated Photodynamic Therapy: Implication for Clinical Ex Vivo Purging of Autologous Stem Cell Transplants. Photochem Photobiol. 2000;72(6):780-7.

12. Huang $\mathrm{H}$, Chen $\mathrm{Y}$, Chen W, Wu Y. Purging efficacy of $\mathrm{ZnPcH}(1)$-based photodynamic therapy on chronic myeloid leukemia bone marrow. Int J Lab Hematol. 2011;33(5):477-82.

13. Barth BM, I Altinoğlu E, Shanmugavelandy SS, Kaiser JM, Crespo-Gonzalez D, DiVittore NA, et al. Targeted indocyanine-green-loaded calcium phosphosilicate nanoparticles for in vivo photodynamic therapy of leukemia. ACS Nano. 2011:5(7):5325-37.

14. Shahzidi S, Čunderlíková B, Więdłocha A, Zhen Y, Vasovič V, Nesland JM, et al. Simultaneously targeting mitochondria and endoplasmic reticulum by photodynamic therapy induces apoptosis in human lymphoma cells. Photochem Photobiol Sci. 2011;10(11):1773-82.

15. Agostinis $P$, Vantieghem A, Merlevede $W$, de Witte PA. Hypericin in cancer treatment: more light on the way. Int J Biochem Cell Biol. 2002;34(3):221-41.

16. Lavie G, Mazur Y, Lavie D, Meruelo D. The chemical and biological properties of hypericin - a compound with a broad spectrum of biological activities. Med Res Rev. 1995;15(2):111-9.

17. Cole CD, Liu JK, Sheng X, Chin SS, Schmidt MH, Weiss MH, et al. Hypericinmediated photodynamic therapy of pituitary tumors: preclinical study in a GH4C1 rat tumor model. J Neurooncol. 2008;87(3):255-61.

18. Zupko I, Kamuhabwa AR, D'Hallewin MA, Baert L, De Witte PA. In vivo photodynamic activity of hypericin in transitional cell carcinoma bladder tumors. Int J Oncol. 2001;18(5):1099-105.

19. Liu CD, Kwan D, Saxton RE, McFadden DW. Hypericin and photodynamic therapy decreases human pancreatic cancer in vitro and in vivo. J Surg Res. 2000;93(1):137-43. 
20. Vantieghem A, Assefa Z, Vandenabeele P, Declercq W, Courtois S, Vandenheede JR, et al. Hypericin-induced photosensitization of HeLa cells leads to apoptosis or necrosis. Involvement of cytochrome $\mathrm{c}$ and procaspase-3 activation in the mechanism of apoptosis. FEBS Lett. 1998:440(1-2):19-24

21. Berlanda J, Kiesslich T, Oberdanner CB, Obermair FJ, Krammer B, Plaetzer K. Characterization of apoptosis induced by photodynamic treatment with hypericin in A431 human epidermoid carcinoma cells. J Environ Pathol Toxicol Oncol. 2006;25(1-2):173-88.

22. Ali SM, Olivo M. Bio-distribution and subcellular localization of Hypericin and its role in PDT induced apoptosis in cancer cells. Int J Oncol. 2002;21(3):531-40

23. Miccoli L, Oudard S, Sureau F, Poirson F, Dutrillaux B, Poupon MF. Intracellular $\mathrm{pH}$ governs the subcellular distribution of hexokinase in a glioma cell line. Biochem J. 1996;313(Pt 3):957-62.

24. Miccoli L, Beurdeley-Thomas A, De Pinieux G, Sureau F, Oudard S, Dutrillaux B, et al. Light-induced photoactivation of hypericin affects the energy metabolism of human glioma cells by inhibiting hexokinase bound to mitochondria. Cancer Res. 1998;58(24):5777-86.

25. Vantieghem A, Xu Y, Assefa Z, Piette J, Vandenheede JR, Merlevede W, et al. Phosphorylation of $\mathrm{BCl}-2$ in $\mathrm{G} 2 / \mathrm{M}$ phase-arrested cells following photodynamic therapy with hypericin involves a CDK1-mediated signal and delays the onset of apoptosis. J Biol Chem. 2002;277(40):37718-31.

26. Assefa Z, Vantieghem A, Declercq W, Vandenabeele P, Vandenheede JR, Merlevede $\mathrm{W}$, et al. The activation of the c-Jun N-terminal kinase and p38 mitogen-activated protein kinase signaling pathways protects HeLa cells from apoptosis following photodynamic therapy with hypericin. J Biol Chem. 1999;274(13):8788-96.

27. Hendrickx N, Volanti C, Moens U, Seternes OM, de Witte P, Vandenheede JR, et al. Up-regulation of cyclooxygenase-2 and apoptosis resistance by $\mathrm{p} 38$ MAPK in hypericin-mediated photodynamic therapy of human cancer cells. J Biol Chem. 2003;278(52):52231-9.

28. Hendrickx N, Dewaele M, Buytaert E, Marsboom G, Janssens S, Van Boven M, et al. Targeted inhibition of p38alpha MAPK suppresses tumor-associated endothelial cell migration in response to hypericin-based photodynamic therapy. Biochem Biophys Res Commun. 2005:337(3):928-35.

29. Wessels JT, Busse AC, Rave-Frank M, Zanker S, Hermann R, Grabbe E, et al. Photosensitizing and radiosensitizing effects of hypericin on human renal carcinoma cells in vitro. Photochem Photobiol. 2008;84(1):228-35.

30. Räz B, Iten M, Grether-Bühler Y, Kaminsky R, Brun R. The Alamar Blue ${ }^{\circledast}$ assay to determine drug sensitivity of African trypanosomes $(<\mathrm{i}\rangle \mathrm{Tb}$ rhodesiense $</ \mathrm{i}\rangle$ and $<\mathrm{i}>$ Tb gambiense</i>) in vitro. Acta Trop. 1997;68(2):139-47.

31. Yuan Y-J, Ge Z-Q, Li J-C, Wu J-C, Hu Z-D. Differentiation of apoptotic and necrotic cells in suspension cultures of Taxus cuspidata by the combined use of fluorescent dying and histochemical staining methods. Biotechno Lett. 2002;24(1):71-6.

32. Shimizu S, Eguchi $Y$, Kamiike W, Itoh Y, Hasegawa J, Yamabe K, et al. Induction of apoptosis as well as necrosis by hypoxia and predominant prevention of apoptosis by BCl-2 and BCl-XL. Cancer Res. 1996;56(9):2161-6.

33. Cossarizza A, Franceschi C, Monti D, Salvioli S, Bellesia E, Rivabene R, et al. Protective effect of $\mathrm{N}$-acetylcysteine in tumor necrosis factor-alpha-induced apoptosis in U937 cells: the role of mitochondria. Exp Cell Res. 1995;220(1):232-40

34. Garner DL, Thomas CA. Organelle-specific probe JC-1 identifies membrane potential differences in the mitochondrial function of bovine sperm. Mol Reprod Dev. 1999:53(2):222-9.

35. Shi J, Zheng D, Liu Y, Sham MH, Tam P, Farzaneh F, et al. Overexpression of soluble TRAIL induces apoptosis in human lung adenocarcinoma and inhibits growth of tumor xenografts in nude mice. Cancer Res. 2005;65(5):1687-92.

36. Lee TK, Man K, Ho JW, Sun CK, Ng KT, Wang XH, et al. FTY720 induces apoptosis of human hepatoma cell lines through PI3-K-mediated Akt dephosphorylation. Carcinogenesis. 2004;25(12):2397-405.

37. Xu R, Harrison PM, Chen M, Li L, Tsui TY, Fung PC, et al. Cytoglobin overexpression protects against damage-induced fibrosis. Mol Ther. 2006;13(6):1093-100

38. Ferlay J, Soerjomataram I, Dikshit R, Eser S, Mathers C, Rebelo M, et al. Cancer incidence and mortality worldwide: sources, methods and major patterns in GLOBOCAN 2012. Int J Cancer. 2014.

39. Dunn JD. Multiple myeloma is. 2012

40. Hendrickx N, Volanti C, Moens U, Seternes OM, de Witte P, Vandenheede JR, et al. Up-regulation of cyclooxygenase-2 and apoptosis resistance by p38
MAPK in hypericin-mediated photodynamic therapy of human cancer cells J Biol Chem. 2003:278(52):52231-9.

41. Vantieghem A, Assefa Z, Vandenabeele P, Declercq W, Courtois S, Vandenheede JR, et al. Hypericin-induced photosensitization of HeLa cells leads to apoptosis or necrosis: Involvement of cytochrome $\mathrm{c}$ and procaspase-3 activation in the mechanism of apoptosis. FEBS Lett. 1998;440(1):19-24.

42. Assefa Z, Vantieghem A, Declercq W, Vandenabeele $P$, Vandenheede JR, Merlevede $\mathrm{W}$, et al. The activation of the c-Jun N-terminal kinase and p38 mitogen-activated protein kinase signaling pathways protects HeLa cells from apoptosis following photodynamic therapy with hypericin. J Biol Chem. 1999:274(13):8788-96.

43. Agostinis P, Assefa Z, Vantieghem A, Vandenheede JR, Merlevede W, De Witte P. Apoptotic and anti-apoptotic signaling pathways induced by photodynamic therapy with hypericin. Adv Enzyme Regul. 2000;40:157-82.

44. Ali SM, Olivo M. Mechanisms of action of phenanthroperylenequinones in photodynamic therapy (review). Int J Oncol. 2003;22(6):1181-91.

45. Moor AC. Signaling pathways in cell death and survival after photodynamic therapy. J Photochem Photobiol B Biol. 2000;57(1):1-13.

46. Kiesslich T, Krammer B, Plaetzer K. Cellular mechanisms and prospective applications of hypericin in photodynamic therapy. Curr Med Chem. 2006;13(18):2189-204.

47. Chao DT, Korsmeyer SJ. BCL-2 family: regulators of cell death. Annu Rev Immunol. 1998;16(1):395-419.

48. Kroemer G, Galluzzi L, Brenner C. Mitochondrial membrane permeabilization in cell death. Physiol Rev. 2007:87(1):99-163.

49. Cheng C-Y, Su C-C. Tanshinone IIA may inhibit the growth of small cell lung cancer $\mathrm{H} 146$ cells by up-regulating the $\mathrm{Bax} / \mathrm{BCl}-2$ ratio and decreasing mitochondrial membrane potential. Mol Med Rep. 2010;3(4):645-50.

50. Marsden VS, O'Connor L, O'Reilly LA, Silke J, Metcalf D, Ekert PG, et al. Apoptosis initiated by $\mathrm{BCl}-2$-regulated caspase activation independently of the cytochrome c/Apaf-1/caspase-9 apoptosome. Nature. 2002;419(6907):634-7.

51. Pieper AA, Verma A, Zhang J, Snyder SH. Poly (ADP-ribose) polymerase, nitric oxide and cell death. Trends Pharmacol Sci. 1999;20(4):171-81.

52. Cregan SP, Dawson VL, Slack RS. Role of AIF in caspase-dependent and caspase-independent cell death. Oncogene. 2004;23(16):2785-96.

\section{Submit your next manuscript to BioMed Central and take full advantage of:}

- Convenient online submission

- Thorough peer review

- No space constraints or color figure charges

- Immediate publication on acceptance

- Inclusion in PubMed, CAS, Scopus and Google Scholar

- Research which is freely available for redistribution 